\title{
Isolation and Pathogenecity Study of Agrobacterium From Rhizospheric Soil of Albizia Saman
}

\author{
X. Asbin Mary ${ }^{1}$, Ann Maria Varghese ${ }^{2}$, J. Jayasurya ${ }^{3}$, S. Sindhuja ${ }^{4}$, \\ S. Gayathri Devi ${ }^{5}$ \\ ${ }^{1}$ Assistant Professor, Alpha Arts and Science College, Porur, Chennai 116, aswinmary87@gmail.com \\ 2,3,4,5 Department of Biotechnology, Alpha Arts and Science College, Porur, Chennai 116.
}

\begin{abstract}
Agrobacterium is a soil borne bacterium that causes the crown gall disease, which is the formation of crown gall tumours on a wide range of plants including dicots and monocots. Most of the genes that are required for the infection process are found on Ti plasmid (Tumor inducing plasmid). The Ti plasmid may carry useful virulence genes that may enhance the plant transformation efficiency. Agrobacterium species have been genetically modified and used as a tool for engineering desired genes into plants. However, many plants remain recalcitrant to genetic transformation by Agrobacterium species resulting in low transformation frequency. This seriously impeded the progress of plant biotechnology, particularly crop improvement.
\end{abstract}

Keywords: Agrobacterium, crown gall tumor, Ti plasmid

\section{Introduction}

Agrobacterium is a soil borne bacterium. It is a member of family - Rhizobiaceae. They are Gram negative, rod - shaped, flagellated and motile bacteria that grows aerobically without forming endospores [1]. Its virulent strains cause crown gall disease and infect dicotyledonous plant of about 90 different families and about a few monocotyledonous plants [2]. Keane et al. (1970) suggested that the genus Agrobacterium be subdivided into two biovars. Subsequently, a third group, biovar3 was described and includes isolates from grapevine [3]. It can infect a wide range of plant species and it can survive in plants, in nurseries, vineyard, and fruit plants as well as in soil [4][5].It infects the roots of dicotyledonous plants through lesions or injuries and hence systematically infects the whole plants. These wounds may be caused by biological agents such as nematodes, insects or mechanical tools[6][7][8]. Agrobacterium can transform virtually any living cells, from other prokaryotes [9] to yeast [10] and fungi [11] [12] to human cells [13]

The DNA transmission capabilities of Agrobacterium have been discovered by Schell and Van Montagu (1977) and development of methods to alter Agrobacterium into an efficient delivery system for gene engineering in plants and makes it of great concern to agriculture [14]. The mechanism, by which Agrobacterium inserts materials into the host cell by a type IV secretion system, is very similar to mechanisms used by animal pathogens to insert materials (usually proteins) into human cells also by type IV secretion [15]. This makes Agrobacterium an important topic of medical research as well. Besides, it plays a vital role in aspect of anti-tumour studies [16][17].

\subsection{Collection of soil sample}

\section{Materials And Methods}

Soils sample were collected from the rhizospheric area of Albizia saman at Arignar Anna Zoological Park, Vandalur, Chennai.

\subsection{Serial Dilution of soil sample}

$1 \mathrm{~g}$ of soil sample and $9 \mathrm{ml}$ of sterile distilled water were taken as stock. Then serial dilution was performedranges from $10^{-1}$ to $10^{-9}$.

\subsection{Isolation of Agrobacterium on Yeast Extract Mannitol Media (YEM)}

$\begin{array}{ll}\text { Ingredients } & \text { Gms/Litre } \\ \text { Yeast Extract } & 1.000 \\ \text { Mannitol } & 10.000 \\ \text { Dipotassium phosphate } & 0.500 \\ \text { Magnesium sulphate } & 0.200 \\ \text { Sodium chloride } & 0.100 \\ \text { Agar } & 15.000 \\ \left.\text { Final pH (at } 25^{\circ} \mathrm{C}\right) & 7.0 \pm 0.2\end{array}$

\section{Composition}


YEM Agar is widely used for the cultivation of Agrobacterium species. A loopful of sample were taken from the serially diluted test tubes and inoculated into the prepared YEM plates and kept for incubation at $37^{\circ} \mathrm{C}$ for 48 hours. After incubation, colonies were white to cream colour, smooth, glistering circular with entire edges and mucoid. [18]

\subsection{Gram staining}

A loopful of culture was taken from the YEMA plates and Gram staining was performed. The colour and morphology of cells were viewed under 100X magnification by using a light microscope with the aid of immersion oil. Pink colour rod shaped bacteria were observed under the microscope. (Figure 1)

\subsection{Motility test:}

A clean, grease free depression slide was taken and 15-20 $\mu 1$ of culture was placed in the middle of the slide. Petroleum jelly was applied on four corners and cover slip is placed on it and then the depression slide was turned upside down. The preparation was examined under microscope, first under 10X, followed by $40 \mathrm{X}$ and 100X magnification. Motile organisms were identified. (Figure 3)

\subsection{Biochemical tests}

Biochemical test of isolates was done according to Bergey's manual of Determinative Bacteriology [19][20][21].

\subsection{Catalase test}

This test was performed by using Direct Plate Method. Pour 3\% hydrogen peroxide was added to the colonies on the agar plates and bubbles were observed which indicates that the Catalase test was positive. (Figure 2)

\subsection{Urease test}

Urea Agar is used to detect Urease production by the isolated organism. Christensen Urea media slants were prepared and a loopful of culture was streaked over the slants. Pink colour change indicates the Urease activity.

\subsection{Growth on Leuria Bertoni media}

LB media was prepared and a loopful of culture was streaked into it and kept for incubation. White colour colonies were grown on the media indicates the positive result.

\subsection{Growth on MacConkey media}

MacConkey media was prepared and a loopful of culture was inoculated into it and kept for incubation. Creamy White colour colonies were grown on the media indicates the positive result.

\subsection{Carrot Disc Assay}

\section{Pathogenecity Test}

YEM broth was prepared and a loopful of culture was added and kept for the formation of turbidity. In laminar air flow, Daucus carota discs were prepared with uniform height and width. Then the bacterial cell suspension was swabbed on the surface of Daucus carota and kept for incubation in growth chamber at $28^{\circ} \mathrm{C}$. Each glass plate was tightly sealed with parafilm to keep the internal environment moist. Every discwas checked for the development of undifferentiated cells one week post inoculation. Tumour formation in the Daucus carota confirmed the phytopathogenicity of the Agrobacterium. (Figure 4)

\subsection{Potato Disc Assay}

YEM broth was prepared and a loopful of culture was added and kept for the formation of turbidity. In laminar air flow, Solanum tuberosum discs were prepared with uniform height and width. Then the bacterial cell suspension was swabbed on the surface of Solanum tuberosum and kept for incubation in growth chamber at $28^{\circ} \mathrm{C}$. Each glass plate was tightly sealed with parafilm to keep the internal environment moist. Every discwas checked for the development of undifferentiated cells one week post inoculation. Tumour formation in the potato confirmed the phytopathogenicity of the Agrobacterium. (Figure 5)

\section{Results}

The present study was conducted to determine the Biochemical and Pathogenicity of Agrobacterium isolated from rhizospheric soil.

\subsection{Isolation of Agrobacterium from soil sample}

Soils sample were collected from the rhizospheric area of Albizia saman at Arignar Anna Zoological Park. Serial dilution was performed ranges from $10^{-1}$ to $10^{-9}$.

\subsection{Isolation of Agrobacterium}

Bacterial colonies were isolated from rhizospheric soil after 48hours of incubation; the bacterial colonies were visible on Yeast Extract Mannitol Agar Plate. The bacterial colonies were also visible on Leuria Bertoni and MacConkey Agar plates. From these initial results, isolated bacteria were identified as Agrobacterim. 


$\begin{array}{ll}\text { 5.3 Characterization of Agrobacterium } \\ \text { 5.3.1Biochemical Test: } & \text { Result } \\ \text { Biochemical Test } & \text { Positive } \\ \text { Catalase } & \text { Positive } \\ \text { Urease } & \text { Motile } \\ \text { Motility } & \end{array}$

\subsubsection{Pathogenicity test}

The isolates were found to be positive in pathogenicity test and produced tumours on carrot and potato disc assays.

\section{Conclusion}

In the present study, the crown gall caused by Agrobacterium becoming a big threatens to nursery and fruit production. It may be a sensitive and specific detection method for the early pathogen diagnosis for symptomless host plant due to the specific infection mechanism. Latest diagnosis is more important since symptomless seedling and soil are the main sources of the disease, and according to the specific invasion mechanism it is hard to control in case of symptom emerged. Many plant species remain recalcitrant to genetic modification using Agrobacterium species yet some researches were successfully in obtaining transgenic plants through Agrobacterium-mediated transformation [22]. As an example, 'Golden Rice', a genetically modified crop with its nutrition values enhanced through Agrobacterium-mediated transformation, providing man with additional vitamins $\mathrm{A}$ for better vision and immunity system [23].

\section{Acknowledgement}

We would like to extend our sincere thanks to Dr. G. Selvamangai, Head of the Department, Alpha Arts and Science College for her support throughout the completion of our project. We thank Ms. Anjana Warrier, Ms. Shenbagam Rathinam and Ms. Mary Swarnalatha for their encouragement.

\section{References}

[1]. Collins A. (2001). Agrobacterium tumefaciens. http://www.cals. ncsu.edu/course/pp728/Agrobacterim/Alyssa_Collins_profile.htm, Cited 23 Feb 2009

[2]. Cleene M. D., Ley J. D. (1976). The host range of crown gall. Bot Rev 42: 389-466 Collins A. (2001).

[3]. Kerr, A. \& Panagopoulos, C.G. (1977). Biotypes of Agrobacterium radiobacter var. tumefaciens and their biological control. Phytopathol Z 90, 172-179.

[4]. Abussaoud, M.J.I.; and Al-Momani, F. Microbial survey of the genus Agrobacterium in grapevine nurseries in Jordan. Arab Gulf J. Scient. Res. 1992, 10, 121-131.

[5]. Ponsonnet, C.; and Nesme, X. Identification of Agrobacterium Strains by PCR-RFLP Analysis of pTi and Chromosomal Regions. Archive Microbiology 1994,6, 300-309.

[6]. Kersters K. and Deley J., Genus III. Agrobacterium. Conn. Bergey's manual of systemematic bacteriology, Vol. 1, $244-254,1984$.

[7]. Woese, C.R., Stackebrandt, E., Weisberg, W.G., Paster, B.J., et al., The phylogeny of purpule bacteria: the alpha subdivision. Syst. Appl. Microbiol, 5, 305-313, 1984.

[8]. Bouzar H., Daouzli N., Krimi Z., Alim A., Khemici E., Crown gall incidence in plant nurseries of Algeria, characteristics of Agrobacterium tumefaciens strains, and biological control of strains sensitive and resistant to agrocine 84, Agronomie., Vol. 11, 901-908, 1991

[9]. Kelly B.A., Kado C.I. (2002). Agrobacterium-mediated T-DNA transfer and integration into the chromosome of Streptomyces lividans.Mol Plant Pathol 3:125-134.

[10]. Piers K. L., Heath J. D., Liang X., Stephens K. M., Nester E. W. (1996). Agrobacterium tumefaciens-mediated transformation of yeast. ProcNatlAcadSci 93:1613-1618.

[11]. Groot M. J. A. D., Bundock P., Hooykass P. J. J., Beijersbergen A. G M. (1998). Agrobacterium tumefaciens-mediated transformation of filamentous fungi. Nat Biotechnol 16:839-842.

[12]. Gouka R. J., Gerk C., hooykaas P. J., Bundock P., Musters W., Verrips C. T., de Groot M. J. A. (1999). Transformation of Aspergillusawamori by Agrobacterium tumefaciens-mediated homologous recombination. Nat Biotechnol 17(6):598-601.

[13]. Kunik T., Tzfira T., Kapulnik Y., Gafni Y., Dingwall C., Citovsky V. (2001). Genetic transformation of HeLa cells by Agrobacterium. ProcNatlAcadSci 98:1871-1876.

[14]. Moore, L.W., W.S. Chilton and M.L. Canfield, 1997. Diversity of opines and opine-catabolizing bacteria isolated from naturally occurring crown gall tumors. Applied Environ. Microbiol., 63: 201-207.

[15]. Lai, K.M. and C.M. Kado, 2000. The T-pilus of Agrobacterium tumefaciens. Trends Microbiol., 8: $361-369$.

[16]. Hussain, A., M. Zia., and B. Mirza, 2007. Cytotoxic and antitumor potential of FagoniacreticaL Turk J. Biol., 31: 19-24.

[17]. Ibrahim, A.M.M., M.H. Mostafa, M.H. El-Masry and M.M.A. El-Naggar, 2005. Active biological materials inhibiting tumor initiation extracted from marine algae Egyp J Aqua. Res., 31:146-155.

[18]. Shams, M., Campillo, T., Lavire, C., Muller, D., Nesme, X. and Vial, L., 2012. Rapid and Efficient Methods to Isolate, Type Strains and Determine Species of Agrobacterium spp. in Pure Culture and Complex Environments. Biochemical Testing, InTech.

[19]. Holt J. G., Krieg N. R., Sneath P. H. A., Staley J. T., Williams S. T. (1994). Bergey's manual of determinative bacteriology. 9th edn. Williams \& Wilkins, Baltimore, Maryland, html, Cited 22 Jan 2009.

[20]. Moore L.W. (1988). Agrobacterium. Laboratory guide for identification of plant pathogenic bacteria (CI Kado, H Bouzar, eds), 2nd ed. American Phytopathological Society Press, St. Paul, MN, 16-36.

[21]. Sawada H., Ieki H. (1992) Phenotypic characteristics of the genus Agrobacterium. Ann PhytopatholSocJpn 58:37-45. 
[22]. Chateau, S., Sangwan, R. and Sangwan-Norreel, B., 2000. Competence of Arabidopsis thaliana genotypes and mutants for Agrobacterium tumefaciens- mediated gene transfer: role of phytohormones. Journal of experimental botany, 51(353), pp.19611968.

[23]. Swanston, A., 2014. Genetically Modified (GM) Crops- Friend or Foe?. [online] Antisense Science. Availableat: <http://antisensescienceblog.wordpress.com/2014/03/25/genetically-modified- gm-crops-friend-or-foe/> [Accessed 9 Apr. 2014].

\section{Figures}

Figure 1 showing Gram negative rods

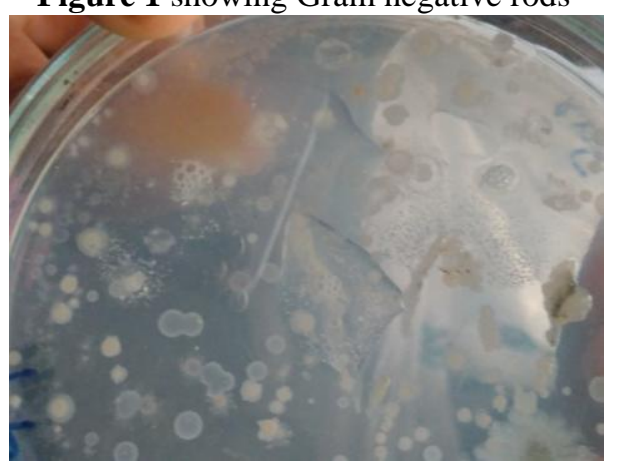

Figure 2 showing positive results for catalase

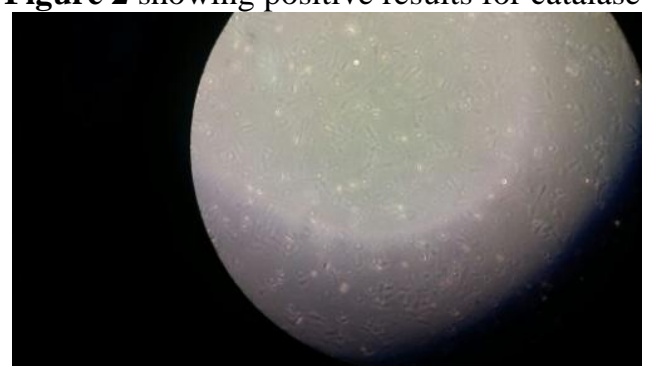

Figure 3 showing motile bacteria

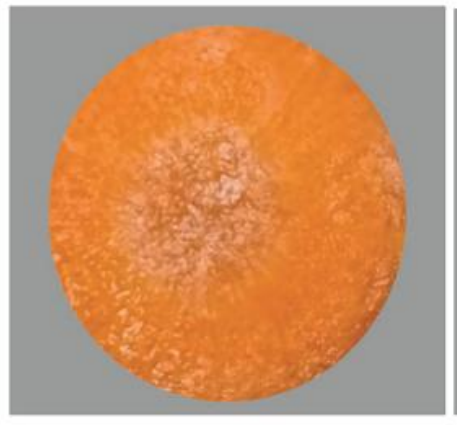

rontrol

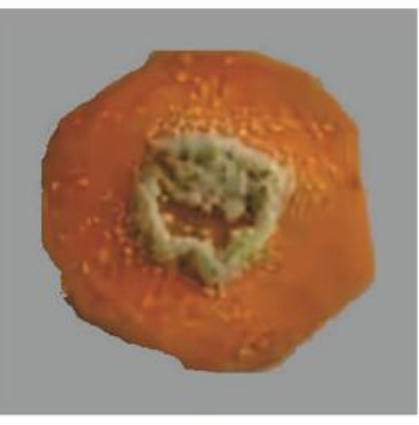

Tumor formation

Figure 4 showing positive results for Carrot disc assay 


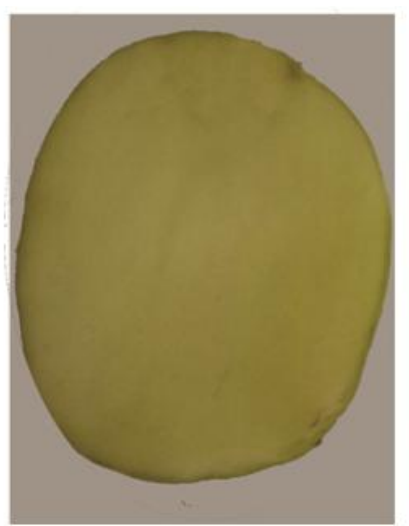

control

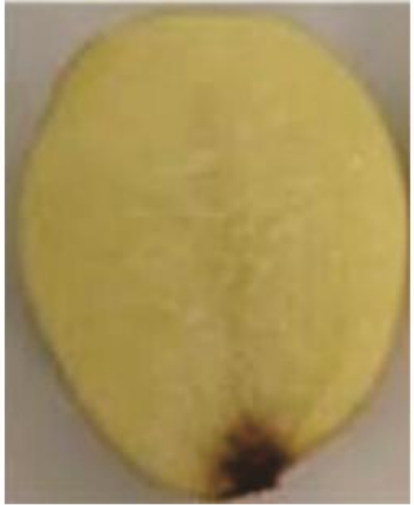

Tumor formation

Figure 5 showing positive results for Potato disc assay 